\title{
Commentary: standardization of nonsteroidal regulators of gonadotrophin secretion
}

\author{
M. P. Rose ${ }^{I}$ and R. E. Gaines-Das ${ }^{2}$ \\ ${ }^{2}$ Division of Endocrinology and ${ }^{2}$ Informatics Laboratory, National Institute for Biological Standards and \\ Control, Blanche Lane, South Mimms, Potters Bar, Hertfordshire EN6 3QG, UK
}

The concept of nonsteroidal regulators of gonadotrophin secretion originated with the identification of inhibin - a hormone produced by the gonads that selectively inhibits the secretion of pituitary follicle stimulating hormone $(\mathrm{FSH})$ - the existence of which was postulated some 70 years ago (Mottram and Cramer, 1923; McCullagh, 1932). However, the purification and characterization of inhibin was a long and arduous task confounded by many factors, including the wide range of starting materials, the different bioassay systems used to define and estimate inhibin activity, the properties of the protein that rendered it resistant to standard protein purification techniques, and the absence of a generally accepted reference preparation for inhibin activity (Findlay, 1986).

In addition to being a member of a wider family of proteins with diverse biological activities in a number of systems, inhibin itself is a complex protein existing as different molecular mass forms as well as products of different genes (for example see Findlay, 1986; Mason et al., 1986; Stewart et al., 1986; Robertson et al., 1992). Inhibin is now known to be a heterodimeric glycoprotein composed of an $\alpha$ subunit and a $\beta$ subunit which are not covalently linked. The $\beta$ subunit occurs in two different forms, termed $\beta A$ and $\beta B$, giving rise to inhibin $A$ and inhibin $B$ on combination with the $\alpha$ subunit. The $\beta$ subunits are also known to combine together to give rise to a molecule which is termed activin on account of its ability to stimulate FSH secretion from the pituitary. Activin can exist in at least three forms: activin $A$, activin $A B$ and activin $B$, depending upon the $\beta$ subunit composition. Robertson $e$ t al. (1995, 1996), using a fractionation procedure, reported the identification of a range of bioactive and immunoactive forms of inhibin in human plasma. These forms have molecular masses of $28-128 \mathrm{kDa}$, attributed to differences in glycosylation of the $\alpha$ subunit and differential processing of the $\alpha$ and $\beta$ subunits. Importantly, in human female serum the majority of these forms appear to be bioactive. Robertson $e t$ al. $(1995,1996)$ conclude that fractionation of serum inhibins can be used to evaluate the specificity of assays used to study inhibin physiology and that their observations highlight the need for appropriate standards, particularly when inhibin is estimated in a clinical setting. The determination of inhibin is further complicated by the secretion and circulation of $\alpha$ subunit precursor proteins (Groome et al., 1995; LambertMesserlian et al., 1995). The identification of molecules that are not structurally related to inhibin, such as follistatin (Nakamura ef al., 1990) and $\alpha_{2}$-macroglobulin (Vaughn and Vale, 1993), which can act as binding proteins for activin and inhibin, may

Received 27 November 1995. lead to interference in both bioassays and immunoassays for inhibin and activin.

During the isolation of inhibin (for example Robertson et al., 1985), research depended upon in vitro biological assays in which classically defined inhibin bioactivity could be detected and estimated, and this activity was displayed by the various local standards, many of bovine, pig or other non-human origin, used in this research. In 1984 the World Health Organization (WHO) Special Program of Research, Development and Research Training in Human Reproduction recognized the need for an ampouled stable reference preparation of inhibin to be made widely available and to serve as a research standard for in vitro bioassays of inhibin. As no standard for human inhibin was available, an extract of pig follicular fluid was provided by the National Institutes of Health $(\mathrm{NIH})$ Contraceptive Development Branch, Bethesda, USA, assessed by an international collaborative study and established as the First International Standard for Inhibin, Porcine. (WHO ECBS, 1990; Gaines-Das et al., 1992).

More recent developments have given rise to immunologically based assays (for example Groome and O'Brien, 1993) and novel in vitro assays (Smyth et al., 1993), which may require highly purified inhibin reference preparations for calibration, and interest in human inhibin in various physiological situations has expanded (for example Muttukrishna et al., 1995). The only source of highly purified human inhibin in sufficient quantity to serve as a standard for such assays is recombinant DNA technology subsequent to the cloning of inhibin (Forage et al., 1986). Therefore, an international collaborative study including preparations of rDNA-derived human inhibin and of human follicular fluid has recently been completed (Rose and Gaines-Das, 1996) and a preparation of rDNA-derived human inhibin deemed suitable to serve as an International Standard for in vitro bioassays and immunoassays was established as the First International Standard for Inhibin, Human, Recombinant, with an assigned unitage of 150000 iu per ampoule. This unitage maintains an approximate continuity with the International Standard for Porcine Inhibin (Code $86 / 690$ ) in the 'original' in vitro bioassays.

The above International Standards for inhibin are available from the National Institute for Biological Standards and Control to support the development of assays for, and research on, the physiological and clinical importance of inhibin. The international collaborative studies that evaluated these standards have highlighted the variability that occurs among estimates made in laboratories using different standards and have also indicated that assay systems currently in use may show markedly different specificities for the various 
components of naturally occurring and recombinant DNAderived inhibins. These findings, along with those described above, demonstrate the need for standard preparations for inhibin, including inhibin $A$, inhibin $B$, different molecular mass forms of inhibin, and for the $\alpha$ and $\beta$ subunits of inhibin. In addition, standards for molecules such as activin and proteins that interact with inhibin, such as follistatin and $\alpha_{2}$-macroglobulin, and the recently identified gonadotrophin surge attenuating/inhibiting factor (GnSAF/GnSIF) (Danforth and Cheng, 1995) may be useful. However, further development of inhibin standards awaits a consensus from the scientific research community on prioritization of the potential multitude of reference reagents. Many of these materials are currently in short supply and are not available in sufficient quantities to serve as International Standards. Mechanisms for producing the required materials in large quantities should be sought. As a WHO International Laboratory for Biological Standards we welcome comments from interested parties.

\section{References}

Danforth DR and Cheng CY (1995) Purification of a candidate gonadotrophin surge inhibiting factor from porcine follicular fluid Endocrinology 136 $1658-1665$

Findlay J (1986) The nature of inhibin and its use in the regulation of fertility and diagnosis of infertility Ferfility and Sterility 46 770-783

Forage RG, Ring JM, Brown RW, McInerney RW, Coban GS, Gregson RP, Robertson DM, Morgan FJ, Hearn MTW, Findlay JK, Wetterhall REH, Burger HG and de Kretser DM (1986) Cloning and sequence analysis of cDNA coding for the two subunits of inhibin from bovine follicular fluid Proceedings of the National Academy of Siences USA 83 3091-3095

Gaines-Das RE, Rose MP and Zanelli JM (1992) International collaborative study by in vitro bioassays of the First International Standard for porcine inhibin Journal of Reproduction and Fertility 96 803-814

Groome N and O'Brien M (1993) Immunoassays for inhibin and its subunits: further applications of the synthetic peptide approach journal of Immunological Methods 165 167-176

Groome NP, Illingworth PJ, O'Brien M, Priddle J, Weaver K and McNeilly AS (1995) Quantification of inhibin pro-aC-containing forms in human serum by a new ultrasensitive two-site enzyme-linked immunosorbent assay Journal of Clinical Endocrinology and Metabolism 80 2926-2932

Lambert-Messerlian GM, Crowley WF, Jr and Schneyer AL (1995) Extra gonadal $\alpha$-inhibin precursor proteins circulate in male serum journal of Clinical Endocrinology and Metabolism 80 3043-3049

McCullagh DR (1932) Dual endocrine activity of the testis Science 76 $19-20$

Mason AJ, Niall HD and Seeburg PH (1986) Structure of two ovarian inhibins Biochemical and Biophysical Research Communications 135 957-964

Mottram JC and Cramer W (1923) On the general effects of exposure to radium on metabolism and tumour growth in the rat and the special effects on testis and pituitary Quarterly Journal of Experimental Physiology 13209

Muttukrishna S, George L, Fowler PA, Groome NP and Knight PG (1995) Measurement of serum concentrations of inhibin-A ( $\alpha-\beta A$ dimer) during human pregnancy Clinical Endocrinology 42 391-397

Nakamura T, Takio K, Eto Y, Shibai H, Titani K and Sugino H (1990) Activinbinding protein from rat ovary is follistatin Science $\mathbf{2 4 7} 836-838$

Robertson DM, Foulds LM, Levershen L, Morgan FJ, Hearn MTW, Burger HG, Wetterhall REH and de Kretser DM (1985) Isolation of inhibin from bovine follicular fluid Biochemical and Biophysical Research Communications 126 $220-226$

Robertson DM, Risbridger GP and de Kretser DM (1992) The physiology of testicular inhibin and related proteins Baillières Clinical Endocrinology and Metabolism 6 355-372

Robertson DM, Sullivan J, Watson M and Cahir N (1995) Inhibin forms in human plasma Journal of Endocrinology 144 261-269

Robertson D, Burger HG, Sullivan J, Cahir N, Groome N, Poncelet E, Franchimont P. Woodruff T and Mather JP (1996) Biological and immunological characterisation of inhibin forms in human plasma Journal of Clinical Endocrinology and Metabolism $81669-676$

Rose MP and Gaines-Das RE (1996) International collaborative study by in vitro bioassays and immunoassays of the First International Standard for Inhibin, Human, Recombinant Biologicals 24 1-8

Smyth CD, Miró F, Whitelaw PF, Howles CM and Hillier SG (1993) Ovarian thecal/interstitial androgen synthesis is enhanced by a follicle-stimulating hormone-stimulated paracrine mechanism Endocrinology 133 1532-1538

Stewart AG, Millborrow HM, Ring JM, Crowther CE and Forage RG (1986) Human inhibin genes: genomic characterisation and sequencing FEBS Letters $206329-334$

Vaughn JM and Vale WW (1993) $a_{2}$-Macroglobulin is a binding protein of inhibin and activin Endocrinology 132 2038-2050

World Health Organisation Expert Committee on Biological Standardization (1990) WHO Technical Report Series No. 800 Annex 4 pp 181-213 